\title{
GADAI SYARIAH DI INDONESIA
}

\author{
Ika Indriasari \\ Universitas PGRI Semarang \\ (ika.antono@gmail.com)
}

\begin{abstract}
Abstrak
Salah satu lembaga keuangan yang telah dirasakan manfaatnya oleh masyarakat selama ini untuk kebutuhan dana yang mendesak adalah pegadaian. Pada beberapa kota besar, pegadaian ini juga menjadi lembaga keuangan yang cukup populer, khususnya menjelang moment-moment khusus seperti hari raya atau saat tahun ajaran baru berlangsung. Dapat dikatakan bahwa masyarakat lebih mudah dengan adanya lembaga keuangan yang dapat mencairkan dana kebutuhan mereka dengan waktu yang relatif sangat cepat, dengan jaminan berupa barangbarang berharga yang dimilikinya. Praktik Rahn merupakan alternatif bagi masyarakat yang memerlukan dana tambahan yang bersifat mendadak yang memenuhi syariat Islam. Sebagian besar masyarakat yang memilih gadai syariah adalah masyarakat yang memang memahami bahwa riba atau bunga dilarang dalam Islam, sehingga pegadaian syariah adalah solusi yang tepat bagi pemenuhan kekurangan dana, pemenuhan kebutuhan yang mendadak maupun alternatif pembiayaan, khususnya untuk investasi emas
\end{abstract}

Kata Kunci: Gadai, Syariah, Keuangan

\section{A. Pendahuluan}

Kebutuhan dana segar pada masyarakat terus meningkat seiring bertambahnya kebutuhan hidup dan terjadinya inflasi. Bagi masyarakat yang memiliki pendapatan cukup, kondisi tersebut tidak terlalu menjadi masalah. Namun bagi masyarakat dengan taraf hidup menengah ke bawah, kebutuhan akan sumber dana yang sewaktu-waktu dapat diandalkan menjadi suatu kebutuhan. Hal ini disebabkan karena tidak semua orang dapat dengan mudah memberikan pinjaman/ utang kepada pihak lain begitu saja. Kehadiran lembaga keuangan yang dapat memberi solusi pemenuhan dana dengan cepat dan mudah, menjadi angin segar bagi masyarakat yang membutuhkannya.

Salah satu lembaga keuangan yang telah dirasakan manfaatnya oleh masyarakat selama ini untuk kebutuhan dana yang mendesak adalah pegadaian. Pada 
beberapa kota besar, pegadaian ini juga menjadi lembaga keuangan yang cukup populer, khususnya menjelang moment-moment khusus seperti hari raya atau saat tahun ajaran baru berlangsung. Dapat dikatakan bahwa masyarakat lebih mudah dengan adanya lembaga keuangan yang dapat mencairkan dana kebutuhan mereka dengan waktu yang relatif sangat cepat, dengan jaminan berupa barang-barang berharga yang dimilikinya.

Sekilas lembaga ini memang terlihat sangat membantu. Motto pegadaian yang berbunyi " mengatasi masalah tanpa masalah" telah mencitrakan sebagai lembaga keuangan yang sangat bersahabat bagi masyarakat. Bagi sebagian masyarakat umum, kehadiran pegadaian memang menjadi solusi, namun bagi masyarakat khususnya masyarakat muslim, ada beberapa praktik yang dilakukan oleh pegadaian terkait dengan adanya bunga yang tidak sesuai dengan syariat. Sebagai contoh, adanya bunga gadai yang pembayarannya dilakukan setiap 15 hari sekali. Pembayaran bunga tersebut harus dilakukan tepat waktu, karena jika terjadi keterlambatan pembayaran, maka bunga gadai akan bertambah menjadi dua kali lipat dari kewajibannya. Bagi masyarakat yang memiliki keterbatasan dana, bunga tersebut tentu memberatkan dan secara jelas terdapat kencenderungan merugikan salah satu pihak. Pada akhirnya, apabila nasabah tidak memiliki uang yang cukup untuk menebus barang dan bunganya, ia harus merelakan barangnya dilelang.

Seiring dengan kesadaran untuk menjalankan ajaran agama, dalam hal ini agama Islam dengan lebih baik, maka tuntutan kebutuhan terhadap lembaga keuangan yang melaksanakan transaksi berdasarkan syariat semakin menguat. Islam membolehkan praktik pinjam meminjam, baik melalui individu maupun lembaga keuangan seperti bank, asuransi, dan sebagainya. Namun dalam ajaran Islam tidak boleh meminta kelebihan dari pokok pinjaman karena termasuk riba. Prinsip dasar muamalah (aktivitas antar manusia) adalah kemaslahatan dan tolong-menolong. Sehingga, dalam praktik perbankan prinsip untuk membantu debitur yang membutuhkan dana dapat dilakukan namun baik pihak kreditur maupun debitur tidak boleh ada yang dirugikan dalam transaksi tersebut. Dapat dikatakan bahwa prinsip syariah dalam gadai menjadi lebih aman dan menguntungkan bagi masyarakat.

Masyarakat telah dapat mendapati berbagai layanan lembaga keuangan yang beroperasi berdasarkan prinsip-prinsip Syariah, termasuk di dalamnya gadai syariah atau disebut juga rahn terhitung sejak tahun 2002, yaitu berdasarkan musyarakah dengan sistem bagi hasil antara Perum Pegadaian dengan Bank Muamalat Indonesia (BMI) dengan maksud agar nasabah BMI yang akan melaksanakan transaksi gadai secara syariah akan dapat dilayani. Dalam 
musyarakah yang tertuang dalam perjanjian No. 446/SP 300.233/202 dan Nomor 015/BMI/PKS/XII/2002 pada tanggal 20 Desember 2002 ini, BMI menjadi pihak yang memberikan modal bagi pendirian pegadaian di seluruh Indonesia. Sedangkan perum Pegadaian merupakan pihak yang menjalankan secara operasional kegiatan pegadaian (Alfisyahri dan Siswantoro, 2012).

Setelah praktik Gadai syariah ini tumbuh dengan pesat di Indonesia, seiring dengan meningkatnya kebutuhan masyarakat terhadap dana segar untuk pemenuhan berbagai kebutuhan mereka. Terkait dengan hal tersebut, lembagalembaga keuangan dan lembaga pegadaian konvensional banyak yang kemudian membuka layanan jasa gadai berbasis syariah. Gadai Syariah ini menjadi layanan yang banyak dijadikan solusi dalam memecahkan masalah kebutuhan dana segar yang dialami oleh masyarakat.

\section{B. Pembahasan}

\section{Landasan Teori}

Secara historis, pegadaian pada awalnya muncul dari Eropa, yaitu pada negaranegara Inggris, Italia, dan Belanda. Sistem pegadaian mulai muncul di Indonesia pada jaman penjajahan Belanda, saat Gubernur Jendral VOC saat itu mendirikan sebuah bank. Bank tersebut memberi jasa pinjaman dana, dengan penyerahan jaminan berupa barang bergerak. Pemerintah sendiri mendirikan lembaaga gadai yang pertama pada tanggal 1 April 1901 di Sukabumi. Tujuan didirikan pegadaian ini semula adalah agar masyarakat saat itu tidak terjerat oleh para lintah darat (Anshori, 2006). Pada perkembangannya, lembaga pegadaian ini mendapatan sambutan yang baik dari masyarakat. Sampai dengan saait ini, pegadaian beroperasi dengan kegiatan usaha utama menyalurkan usaha pinjaman atas dasar hukum gadai, dan menjalankan usaha lainnya seperti jasa titipan, jaminan fidusia, sertifikasi logam mulia dan usaha lainnya dengan dasar hukum PP 103 th. 2000 (Alfisyahri dan Siswantoro, 2012)

Gadai dalam kitab Undang-Undang Hukum Perdata, pasal 1150, adalah suatu hak yang memiliki nilai ekonomis kepada pihak tertentu untuk memperoleh sejumlah uang, barang yang diperoleh seseorang yang mempunyai piutang atas suatu barang bergerak. Dimana barang bergerak tersebut diserahkan kepada orang yang berpiutang oleh orang yang mempunyai hutang atau oleh orang lain atas nama orang yang mempunyai hutang (Piryanti, 2013). Dalam pengertian lain, gadai diartikan sebagai kegiatan menjaminkan barang yang memiliki nilai ekonomis kepada pihak tertentu untuk memperoleh sejumlah uang, barang yang dijaminkan akan ditebus kembali sesuai dengan perjanjian antara nasabah dengan lembaga gadai (Rais, 2004). Praktik gadai ini umum berlaku di berbagai daerah maupun 


\section{Indriasari}

negara, dengan tujuan memperoleh dana segar dalam jangka pendek, dengan menggunakan jaminan barang berharga.

Dalam sistem ekonomi syariah, gadai atau disebut dengan istilah rahn. Secara etimologi, rahn berarti tetap, kekal dan jaminan. Dalam bahasa Arabnya dikenal dengan ats-tsubut wa ad daman (tetap dan kekal), seperti halnya juga dalam kalimat maun rahin, yang berarti air yang tenang. Pengertian tetap dan kekal dimaksud, merupakan makna yang bersifat materil. Karena itu, secara bahasa rahn berarti menjadikan sesuatu barang yang bersifat materi sebagai pengikat utang atau dalam bahasa hukum perundang-undangan disebut sebagai barang jaminan, dan agunan (Piryanti, 2013).

Azhar Basyir menyebutkan bahwa rahn adalah perbuatan menjadikan suatu barang yang bernilai menurut pandangan syara' sebagai tanggungan uang, yang mana dengan adanya benda yang menjadi tanggungan tersebut seluruh atau sebagian utang dapat diterima. Ar Rahn juga diartikan menahan salah satu harta milik si peminjam atas pinjaman yang diterimanya. Barang yang ditahan adalah barang yang memiliki nilai ekonomis. Dengan adanya barang tersebut pihak yang menahan memperoleh jaminan untuk dapat mengambil kembali seluruh atau sebagian piutangnya. Atau secara sederhana, dapat disimpulkan bahwa rahn adalah jaminan hutang atau gadai (Antonio, 1999)

Gadai (rahn) yang diberikan oleh ahli hukum Islam sebagai berikut:

a) Dari Ulama Syafi' iyah, Hanafi dan Malikiyah. Menurut Ulama Syafi'iyah rahn adalah menjadikan materi (barang) sebagai jaminan utang yang dapat dijadikan pembayar utang apabila orang yang berutang tidak bisa membayar utangnya. Ulama Hanafi mendefinisikan Rahn yaitu menjadikan suatu barang sebagai jaminan terhadap hak piutang yang mungkin dijadikan pembayar utang apabila orang yang berutang tidak bisa membayar hutangnya. Ulama Malikiyah mendefinisikan bahwa rahn adalah sesuatu yang bernilai harta (mutamawwal) yang diambil dari pemiliknya untuk dijadikan pengikat atas utang yang tetap (mengikat), menurutnya harta tersebut bukan saja berupa materi, namun juga berupa manfaat.

b) Imam Taqiyuddin dalam hal ini mendefinisikan rahn sebagai akad/perjanjian utangpiutang dengan menjadikan marhun sebagai kepercayaan/penguat marhun bih dan murtahin berhak menjual/ melelang barang yang digadaikan itu pada saat ia menuntut haknya. Barang yang dapat dijadikan jaminan utang adalah semua barang yang dapat diperjualbelikan (bernilai ekonomis), artinya semua barang yang dapat dijual itu dapat digadaikan. 
d) Menurut Ahmad Baraja, rahn adalah jaminan bukan produk dan semata untuk kepentingan sosial, bukan kepentingan bisnis, jual beli atau bermitra. Jadi, menurutnya uang hasil gadai syariah ini tidak boleh dipakai untuk investasi.

e) Muhammad Syafi'I Antonio dalam bukunya, Bank Syariah: Dari Teori ke Praktik, bahwa pengertian gadai atau rahn mengutip pandangan Sayyid Sabiq, adalah menyimpan sementara harta milik sipeminjam sebagai jaminan atas pinjaman yang diberikan oleh sipiutang. Berarti, barang yang dititipkan pada sipiutang dapat diambil kembali dalam jangka waktu tertentu.

Dari berbagai definisi diatas, secara garis besar dapat disimpulkan bahwa rahn itu merupakan suatu akad utang piutang dengan menjadikan barang yang memiliki nilai harta menurut pandangan syara' sebagai jaminan marhun bih (utang).

Dari pendapat-pendapat mengenai ar Rahn tersebut, terdapat beberapa kesamaan, yaitu:

1. Gadai adalah suatu bentuk transaksi yang dikategorikan sebagai utang piutang

2. Untuk mendapatkan kepercayaan dari orang atau pihak yang meminjamkan uang, maka orang yang berhutang menggadaikan barangnya sebagai jaminan atas utangnya $\mathrm{i}$

3. Barang jaminan atas utang tersebut dapat dijual untuk membayar utang orang yang berhutang, baik senilai sebgian atau keseluruhan. Apabila dalam penjualan barang jaminan terdapat kelebihan, sementara orang yang menerima jaminan mengambil sebagiannya yaitu sebesar uang yang dipinjamkannya.

4. Barang jaminan tetap milik orang yang menggadaikan (0rang yang berpiutang), tetapi dikuasai oleh penggadai (orang yang berpiutang)

5. Gadai menurut syariat Islam berarti penahanan atau pengekangan sehingga dengan akad gadai kedua belah pihak mempunyai tanggung jawab bersama, yang punya utang bertanggung jawab melunasi utangnya dan orang yang berpiutang bertanggung jawab menjamin kebutuhan barang jaminannya. Apabila hutang telah dilunasi, maka penahanan atas barang yang disebabkan oleh akad gadai menjadi lepas, sehingga pertanggungjawaban orang yang menggadai dan yang meneria gadai hilang atau telah lepas dari tanggung jawab masing-masing.

6. Pelaksana gadai adalah orang yang memiliki harta benda, karena harta benda yang bukan miliknya tidak dapat digadaikan.

Demikian pengertian Rahn atau gadai menurut syariat Islam. Berdasarkan uraian yang telah disebutkan di atas, gadai dalam syariat Islam mengandung nilai sosial yang tinggi. Dalam praktik rahn ini mestinya tidak ada pihak yang dirugikan dalam bertransaksi. Gadai dalam Islam memiliki nilai sosial yang tinggi, lebih 


\section{Indriasari}

bertujuan untuk menolong pihak yang membutuhkan tanpa merugikan pihak yang meminjamkan, dan pada dasarnya jauh dari tujuan komersial (Yanggo dan Anshory, 2004)

Dalam melaksanakan pelayanan produk gadai atau Rahn, antara pegadaian konvensional dan gadai syariah memiliki beberapa persamaan dan juga perbedaan. Salah satu perbedaan yang mendasar adalah tidak adanya pungutan bunga dalam transaksi gadai syariah karena bunga termasuk dalam riba yang dilarang dalam Islam

\begin{tabular}{|c|l|l|}
\hline \multicolumn{3}{|c|}{ Perbandingan } \\
\hline \multicolumn{2}{|c|}{ Gadai dengan Rahn (Gadai Syari'ah) } \\
\hline INDIKATOR & RAHN (GADAI SYARI'AH) & GADAI KONVENSIONAL \\
\hline $\begin{array}{c}\text { Konsep } \\
\text { Dasar }\end{array}$ & $\begin{array}{l}\text { Tolong Menolong (Jasa } \\
\text { Pemeliharaan Barang } \\
\text { Jaminan) }\end{array}$ & $\begin{array}{l}\text { Profit Oriented (Bunga dari } \\
\text { Pinjaman Pokok / Biaya } \\
\text { Sewa Modal) }\end{array}$ \\
\hline Jenis & $\begin{array}{l}\text { Barang Bergerak \& Tidak } \\
\text { Bergerak }\end{array}$ & Hanya Barang Bergerak \\
\hline Barang Jaminan & Biaya Pemeliharaan & $\begin{array}{l}\text { Bunga (dari pokok } \\
\text { pinjaman) }\end{array}$ \\
\hline Beban & $\begin{array}{l}\text { Bisa Dilakukan Perseorangan } \\
\text { Lembaga }\end{array}$ & $\begin{array}{l}\text { Hanya bisa dilakukan oleh } \\
\text { lembaga (perum Pegadaian) }\end{array}$ \\
\hline & $\begin{array}{l}\text { Di jual (kelebihan } \\
\text { dikembalikan kepada yang } \\
\text { memiliki barang) }\end{array}$ & Di lelang \\
\hline Perlakuan
\end{tabular}

Gambar I. Perbandingan gadai konvensional dengan gadai syariah

Pelaksanaan operasional gadai syariah di Indonesia, sudah seharusnya mengikuti aturan-aturan yang Rahn sebagaimana aturan aslinya untuk menjamin sah dan halalnya transaksi, sehingga masyarakat yang memanfaatkan gadai syariah untuk memenuhi kebutuhan keuangannya dapat terjamin keamanan transaksinya.

\section{Praktik gadai Syariah ( Rahn) di Indonesia}

Kesadaran masyarakat untuk menjalankan kehidupan yang sesuai dengan aturan agama, dalam hal ini khususnya bagi umat Islam mendorong keinginan untuk bertransaksi keuangan yang lebih memenuhi nilai syariah. Islam 
memperbolehkan pinjam meminjam, namun tidak memperbolehkan adanya kelebihan atas pinjaman yang dikembalikan (riba).

Di Indonesia, pegadaian syariah dibentuk sebagai unit bisnis yang mandiri dengan maksud untuk menjawab tantangan kebutuhan masyarakat yang mengharapkan adanya pelayanan pinjam meminjam yang bebas dari unsur riba, maysir dan gharar. Maka, tugas pokok pegadaian syariah adalah melayani kegiatan pemberian pembiayaan kepada masyarakat luas atas dasar penerapan prinsip gadai yang dibenarkan oleh syariat Islam. Perum pegadaian syariah ini dalam menjalankan tugas pokok diatas, maka pegadaian syariah berfungsi sebagai organisasi cabang Perum Pegadaian yang bertanggung jawab mengelola usaha sesuai syariah agar berkembang menjadi institusi syariah yang mandiri dan menjadi pilihan utama warga masyarakat yang membutuhkan pelayanan gadai secara syariah. (Piryanti, 2013)

Dalam menjalankan operasi gadai syariah tersebut, ada beberapa akad yang biasa dilaksanakan, yaitu:

1) Akad Qard al-Hasan. Akad ini biasanya dilakukan pada nasabah yang ingin menggadaikan barangnya untuk tujuan konsumtif. Untuk itu, nasabah (rahin) dikenakan biaya berupa upah/fee kepada pihak pegadaian (murtahin) karena telah menjaga dan merawat barang gadaian (marhun).

Sebenarnya, dalam akad qard al-hasan tidak diperbolehkan memungut biaya kecuali biaya administrasi. Mekanisme pelaksanaan akad qard al-hasan:

a. Barang gadai (marhun) berupa barang yang tidak dapat dimanfaatkan, kecuali dengan jalan menjualnya dan berupa barang bergerak saja, seperti emas, barang elektronik, dan sebagainya.

b. Tidak ada pembagian bagi hasil, karena akad ini bersifat sosial. Tetap diperkenankan menerima fee sebagai pengganti biaya administrasi yang biasanya diberikan pihak pemberi gadai (rahin) kepada penerima gadai (murtahin).

2) Akad Hutang dan jasa

a. Rahin mendatangi murtahin untuk minta fasilitas pembiayaan dengan membawa marhun yang tidak dapat dimanfaatkan/ dikelola yang akan diserahkan kepada murtahin.

b. Murtahin melakukan pemeriksaan, termasuk juga menaksir harga marhun yang diberikan rahin sebagai jaminan utangnya.

c. Setelah semua persyaratan terpenuhi, maka murtahin dan rahin akan melakukan akad. 
d. Selanjutnya, setelah akad dilakukan, maka murtahin akan memberikan sejumlah marhun bih, yang diinginkan rahin dan jumlahnya disesuaikan dengan nilai taksir barang (di bawah nilai jaminan).

e. Sebagai pengganti biaya administrasi dan biaya perawatan, maka pada saat melunasi marhun bih, maka rahin akan memberikan sejumlah fee kepada murtahin.

3) Akad Mudharabah

Akad mudharabah diterapkan untuk nasabah yang menginginkan menggadaikan jaminannya untuk menambah modal usaha (pembiayaan investasi atau modal kerja). Dengan demikian rahin akan memberikan bagi hasil berdasarkan keuntungan usaha yang diperoleh kepada murtahin sesuai dengan kesepakatan. Sampai dengan modal dipinjam terlunasi.

\section{4) Akad Ba'i Muqayyadah}

Sementara akad al-ba'I muqayyadah dapat dilakukan jika rahin yang menginginkan menggadaikan barangnya untuk keperluan produktif, seperti pembelian peralatan untuk modal kerja. Untuk memperoleh pinjaman, nasabah harus menyerahkan barang sebagai jaminan berupa barang-barang yang dapat dimanfaatkan, baik oleh rahin maupun murtahin.Dalam hal ini, nasabah dapat memberi keuntungan berupa mark up atas barang yang dibelikan oleh murtahin. Atau dengan kata lain, murtahin (pihak pegadaian) dapat memberikan barang yang dibutuhkan oleh nasabah dengan akad jual beli, sehingga murtahin dapat mengambil keuntungan berupa margin dari penjualan barang tersebut sesuai dengan kesepakatan antara keduanya.

5) Akad Ijarah

Akad ijarah adalah akad yang objeknya adalah penukaran manfaat untuk masa tertentu, yaitu pemilikan manfaat dengan imbalan, sama dengan menjual manfaat. Dalam kontrak ini ada kebolehan untuk menggunakan manfaat atau jasadengan ganti berupa kompensasi.

Dalam gadai syariah, penerima gadai (murtahin) dapat menyewakan tempat penyimpanan barang (deposit box) kepada nasabahnya. Barang titipan dapat berupa barang yang menghasilkan manfaat maupun tidak menghasilkan manfaat. Pemilik yang menyewakan disebut mustajir, dan sesuatu yang dapat diambil manfaatnya disebut major, sedangkan kompensasi atau balas jasa disebut ujrah.

Transaksi rahn di Indonesia dibagi menjadi dua yaitu rahn biasa dimana marhun dapat terdiri dari segala benda yang memenuhi kententuan syariahnya dan rahn 
emas dimana marhun harus berupa emas. Rahn emas adalah penggadaian atau penyerahan hak penguasa secara fisik atas harta atau barang berharga (berupa emas) dari rahin kepada murtahin sebagai marhun atas marhun bih yang diberikan murtahin kepada rahin (Anshori, 2006). Hal yang menjadi dasar hukum dari praktik rahn emas di Indonesia adalah fatwa DSN MUI No.26/DSNMUI/III/2002 tentang gadai emas syariah. Pada dasarnya transaksi rahn emas memiliki kesamaan dengan rahn biasa baik secara rukun maupun syarat sahnya, yang membedakan kedua transaksi tersebut adalah bahwa pada rahn emas marhun harus berupa emas, sedangkan pada rahn biasa tidak dibatasi dengan emas. Untuk marhun berupa emas tentu tidak ada biaya pemeliharaan sebagaimana marhun barang lainnya, yang ada adalah penyimpanan dimana penentuan besarnya biaya penyimpanan dilakukan dengan akad ijarah (Nurhayari dan Wasilah, 2011). Beban dan biaya penyimpanan marhun tersebut ditanggung oleh rahin.

Akad qardh merupakan akad yang digunakan dalam praktik rahn emas. Hal ini dikarenakan dalam praktik rahin emas, marhun hanya berupa barang yang tidak menghasilkan (tidak dapat dimanfaatkan) yaitu berupa emas. Sehingga murtahin akan mendapatkan biaya upah atau fee dari rahin, karena murtahin telah menjaga dan merawat marhun (dengan kata lain untuk biaya penyimpanan dan pemeliharaan) (Nurhayati dan Wasilah, 2011). Disamping itu murtahin juga diperbolehkan mengenakan biaya administrasi kepada rahin. Dalam akad qardh ini, rahin hanya mengembalikan modal pinjaman dan menggunakan transaksi berdasarkan prinsip biaya administrasi (biaya materai, notaris, biaya pemeliharaan, dan biaya lainnya yang terkait). Jika rahin mengalami kerugian bukan karena kelalaiannya maka kerugian tersebut dapat mengurangi jumlah pinjaman (Nurhayati dan Wasilah, 2011). Sedangkan untuk rukun dan ketentuan syariah akad qardh sama dengan rahn.

Di Indonesia, keberadaan gadai syariah memang bukan hal yang baru. Namun demikian, layanan rahn ternyata masih belum terlalu diketahui oleh masyarakat kecuali masyarakat yang memang sangat ingin melakukan transaksi yang sesuai syariah. Dalam arti, informasi mengenai gadai bebas riba ini akan dicari sendiri oleh nasabah. Hasil wawancara dengan beberapa nasabah yang pernah bertransaksi gadai, menyatakan bahwa mereka sebenarnya tertarik dengan layanan rahn atau gadai syariah, namun belum atau enggan mencari informasi lebih lanjut mengenai layanan tersebut, sehingga masih menggunakan jasa layanan gadai konvensional.

Penelitian mengenai rahn ini pernah dilakukan oleh Maulidia (2003). Hasil penelitian menunjukkan bahwa layanan rahn memberikan solusi untuk nasabah 
yang membutuhkan dana tunai namun dengan tidak menerapkan bunga melainkan biaya titip atau ijarah. Hal ini menjadi daya tarik tersendiri bagi nasabah dan memiliki potensi untuk dimaksimalkan. Oleh karena itu perlu adanya peraturan yang jelas agar lebih optimal bagi masyarakat. Selain itu, perlu juga dilakukan sosialisasi mengenai rahn agar masyarakat lebih mengenal layanan rahn.

Penelitian lainnya dilakukan oleh Alfisyahri dan Dodik, 2012 di Jakarta. Hasil penelitian ini menyatakan bahwa karakteristik nasabah yang melakukan praktik rahn yaitu: mayoritas beragama Islam, perbandingan baik pria maupun wanita yang memanfaatkan layanan ini merata, tingkatan usia yang terbanyak memanfaatkan layanan ini kisaran 26 tahun-34 tahun, jenis pekerjaan nasabah mayoritas karyawan swasta, mayoritas tingkat penghasilan nasabah kurang dari Rp2.500.000, dan rata-rata nasabah melakukan pelunasan barang jaminan sebelum jatuh tempo. Hasil penelitian juga menunjukkan bahwa tujuan melakukan gadai untuk memenuhi kebutuhan hidup menempati peringkat pertama dari motif nasabah melakukan transaksi rahn.

Jika dikaitkan dengan teori motif memiliki uang tunai yang salah satunya adalah motif transaksi dimana didalamnya adalah untuk memenuhi kebutuhan hidup (Anshori, 2006) maka dapat disimpulkan bahwa responden memahami bahwa melakukan gadai syariah dapat membantu responden mendapatkan pembiayaan untuk memenuhi kebutuhan hidupnya. Nasabah rahn juga sangat setuju dengan pernyataan menggadaikan barang untuk antisipasi kebutuhan mendadak. Jika dikaitkan dengan teori motif dari memiliki uang tunai yang salah satunya adalah motif berjaga-jaga maka dapat disimpulkan bahwa responden memahami bahwa melakukan gadai secara syariah dapat membantu responden mendapatkan pembiayaan berupa uang tunai untuk berjaga-jaga dari kebutuhan yang bersifat mendadak dan menyetujui bahwa mereka melakukan gadai syariah dengan motif investasi, nasabah akan mendapatkan keuntungan di masa yang akan datang dengan adanya kenaikan harga atas emas yang digadaikan. Jika dikaitkan dengan teori motif memiliki uang tunai karena motif investasi, maka dari penelitian Alfisyahri dan Dodik (2012) ini dapat disimpulkan bahwa nasabah juga cukup paham jika transaksi rahn dapat dimanfaatkan untuk pembiayaan.

Dari hasil wawancara dengan beberapa responden, diperoleh data bahwa nasabah gadai syariah memilih praktik rahn karena menghindari bunga/ riba. Hal ini juga didukung oleh hasil penelitian dari Alfisyahri dan Dodik (2012) pada nasabah gadai syariah di Jakarta yang menyatakan bahwa nasabah lebih menyukai gadai syariah karena tidak menerapkan bunga atau riba didasarkan atas larangan 
riba tahap keempat dimana Allah SWT melarang keras dan tegas semua jenis riba (Al-Baqarah 278-279).

\section{Kesimpulan}

Praktik Rahn merupakan alternatif bagi masyarakat yang memerlukan dana tambahan yang bersifat mendadak yang memenuhi syariat Islam. Sebagian besar masyarakat yang memilih gadai syariah adalah masyarakat yang memang memahami bahwa riba atau bunga dilarang dalam Islam, sehingga pegadaian syariah adalah solusi yang tepat bagi pemenuhan kekurangan dana, pemenuhan kebutuhan yang mendadak maupun alternatif pembiayaan, khususnya untuk investasi emas. Dalam hal ini, praktik rahn yang benar-benar sesuai dengan syariah harus dijaga agar tidak keluar dari aturan yang semestinya. Akad yang dijalankan, termasuk jasa dan produk yang dijual juga harus berlandaskan syariah dengan tidak melakukan kegiatan usaha yang mengandung unsur riba, maisir, dan gharar. Mekanisme operasional pegadaian syariah merupakan implementasi dari konsep dasar rahn yang telah ditetapkan oleh para ulama fiqih. (Piryanti, 2013)

Kegiatan layanan keuangan syariah, dalam hal ini layanan gadai syariah perlu memperoleh pengawasan ketat dari pihak yang berwenang, dalam hal ini Bank Indonesia terutama pada penyalahgunaan transaksi gadai yang melenceng dari tujuan awal gadai sebagai penyedia dana cepat untuk keperluan mendesak. Dilain pihak, penyelenggara gadai syariah juga perlu memiliki SOP dan peraturan yang dapat mencegah orang menggunakan gadai syariah untuk kepentingan pribadi dan spekulasi semata. 
Indriasari

\section{Daftar Pustaka}

Alfisyahri, Naida Noor; Siswantoro, Dodik, 2012. Praktik dan Karakteristik Gadai Syariah di Indonesia, SHARE, Vol 1, No.2 July- Desember 2012

Anshori, A. G. 2006. Gadai syariah di Indonesia: Konsep, implementasi dan institusionalisasi, Yogyakarta: Gadjah Mada University Press.

Antonio, Muhammad Syafi'I, 1999. Bank Syari'ah suatu Pengenalan umum" Jakarta: Tazkia Institute, 1999, halm 184.

Chuzaimah T. Yanggo, Hafiz Anshory, "Problematika Hukum Islam Kontemporer", Jakarta; 2004 hal 79-82.

Fatwa No.19/DSN-MUI/IX/2000 tentang akad qardh

Fatwa No.25/DSN-MUI/III/ 2002 tentang rahn.

Fatwa No.26/DSN-MUI/III/ 2002 tentang rahn emas

Hamid, S. A \& Aziz, A. A. 2003. "Development of islamic pawn-broking services: Differentiating profiles of their respective patrons". Paper presented at the international islamic banking conference 2003Conference proceedings, 2003

Konsep Gadai Syariah (Ar-Rahn) Dalam Perspektif Ekonomi Islam Dan Fiqh Muamalah Posted: 24/01/2011

Maulidia, L. R. 2003. “The optimizing of rahn service for the development of islamic banking in Indonesia", IQTISAD Journal of Islamic Economics Vol. 4 No. 22, 169-179.

Noverdi, Fajar. 2012. Teori Dan Pelaksanaan Gadai Dalam Perspektif Konvensional

Nurhayati, S. \& Wasilah. 2011. Akuntansi syariah di Indonesia (2nd ed revisi). Jakarta: Salemba Empat, 2011.

Piryanti, Meri ,2013. Operasional Gadai Syariah, Pasca Sarjana UIN Sunan Kalijaga Yogyakarta , $\underline{\text { REP }}$ | 02 December 2013 | 12:00 